\title{
Feasibility Study of Photovoltaic (PV) Modules, and Biomass Generator to Supply Electricity to Auckland City, North Island Context-New Zealand
}

\author{
Harish Kumar R. N., Member, IACSIT
}

\begin{abstract}
Renewable energy (RE) hybrid power system (HPS) is one of the most promising, economical, and reliable option for supplying electricity to Auckland's grid connected electricity. In this paper this is an attempt for pre-analysis investigation to understand the feasibility study of PV, bio mass based generator to supply electricity to Auckland city, North Island context-New Zealand. A HPS was proposed majorly considering $P V$ and to some extent biomass generator i.e. to achieve 100 percent renewable energy (RE) for Auckland city electricity load in order to achieve New Zealand's predicted 90 percent RE target by 2025 . The proposed system was designed in Hybrid Optimization Model for Electric Renewable (HOMER) to performance analysis such as feasibility, sensitivity, cost, and sustainability of HPS. A study for solar energy was conducted among the major cities located in North Island i.e. by collecting solar radiation data from NASA and through numerical approach. Therefore, the conducted study revealed that the selected location in Auckland city has the second highest in receiving solar energy, and is proposed as best suitable to establish $P V$, and biomass based generator RE power plant for future sustainability.
\end{abstract}

Index Terms - Renewable energy (RE), hybrid power system (HPS), photovoltaic (PV), biomass, generator, converter, battery, HOMER.

\section{INTRODUCTION}

Electricity defines the modern world i.e. everything we use and think of the modern world runs on electricity. Today there are various technologies available on earth to produce electricity; the technologies are coal fired power plants, gas turbine and combined cycle power plants, combined heat and power, piston engine based power plant, fuel cells, hydro power, tidal power, wind power, geothermal power, solar power, ocean power, biomass based power generation, power from waste, and nuclear power [1]. Among them the major $\mathrm{RE}$ resources used to generate electricity in New Zealand (NZ) are hydro power, geothermal, and increasingly wind generator. Indeed that most of the electricity produced in NZ is through RE sources and NZ stands 3rd position in using RE sources globally [2].

Though electricity generated resources in NZ are dominated with RE, it is still targeting to achieve 90 percent by 2025 and planning to halt most of the unwanted GHG released in atmosphere [3].

Manuscript received November 5, 2013; revised December 25, 2013

Harish Kumar R N. is with the School of Engineering, Deakin University, 75 Pigdons Rd, Waurn Ponds, Geelong VIC 3216, Australia (e-mail: harish.nvhph@gmail.com).

\section{PROBLEM}

NZ suffers a geographical imbalance between the elecricity consumption and supply as both existing and remaining potential electricity generation plants are located at South Island, where as the major demad (currently and continue to grow) occurs in North Island, especially in Auckland region [4]. The supply of electricity needs transmission networks to transport electricity from South Island to North Island and due to the massive distance of transmission networks, there are some electricity losses due to resistance [5].

NZ's location and topography are considered to be less favourable to solar energy utilization compared to wind and marine power. However a substantial solar energy does exists and the resource available are not limited, but the greater constraint is economic [4].

The grid line capacity in NZ are $50 \mathrm{kV}, 66 \mathrm{kV}, 110 \mathrm{kV}$, $220 \mathrm{kV}, 350 \mathrm{kV}$ high voltage direct current (HVDC) and with intermediate substations which approximately travels 1200 $\mathrm{km}$ of high voltage transmission lines. The national grid transports over 50 power stations and connects with distribution networks at 200 grid exit points (GXPs) [5].

With above all concerns a RE HPS nearly located to the load (utility) can minimize the electricity losses, and cost to implement new transmission networks for future increasing electricity consumption.

\section{SYSTEM MODEL}

The proposed system is as shown in the Fig. 1. The system was a designed majorly with $P V$ modules and remaining with biomass, but the primary target was to achieve 100 percent electricity supply through RE. The system manly consists of 600 kilo watts (kW) $P V, 600 \mathrm{~kW}$ converter, 800 batteries, and single $60 \mathrm{~kW}$ biomass generator.

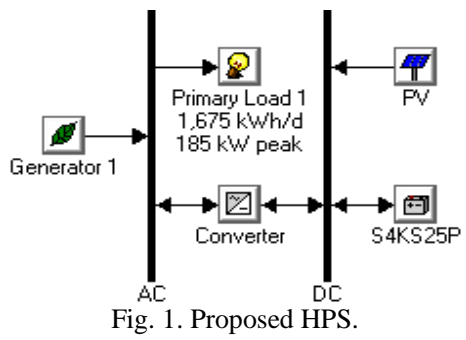

\section{ELECTRICITY LOAD}

The grid connected electricity load profile is as shown in the Fig. 2. The details of the grid connected electricity load 
were provided by "Unison Networks Limited". I would like to specially thank them. The electricity load profile acquirement is not steady as it varies with the change in usage of electricity consumption appliances.

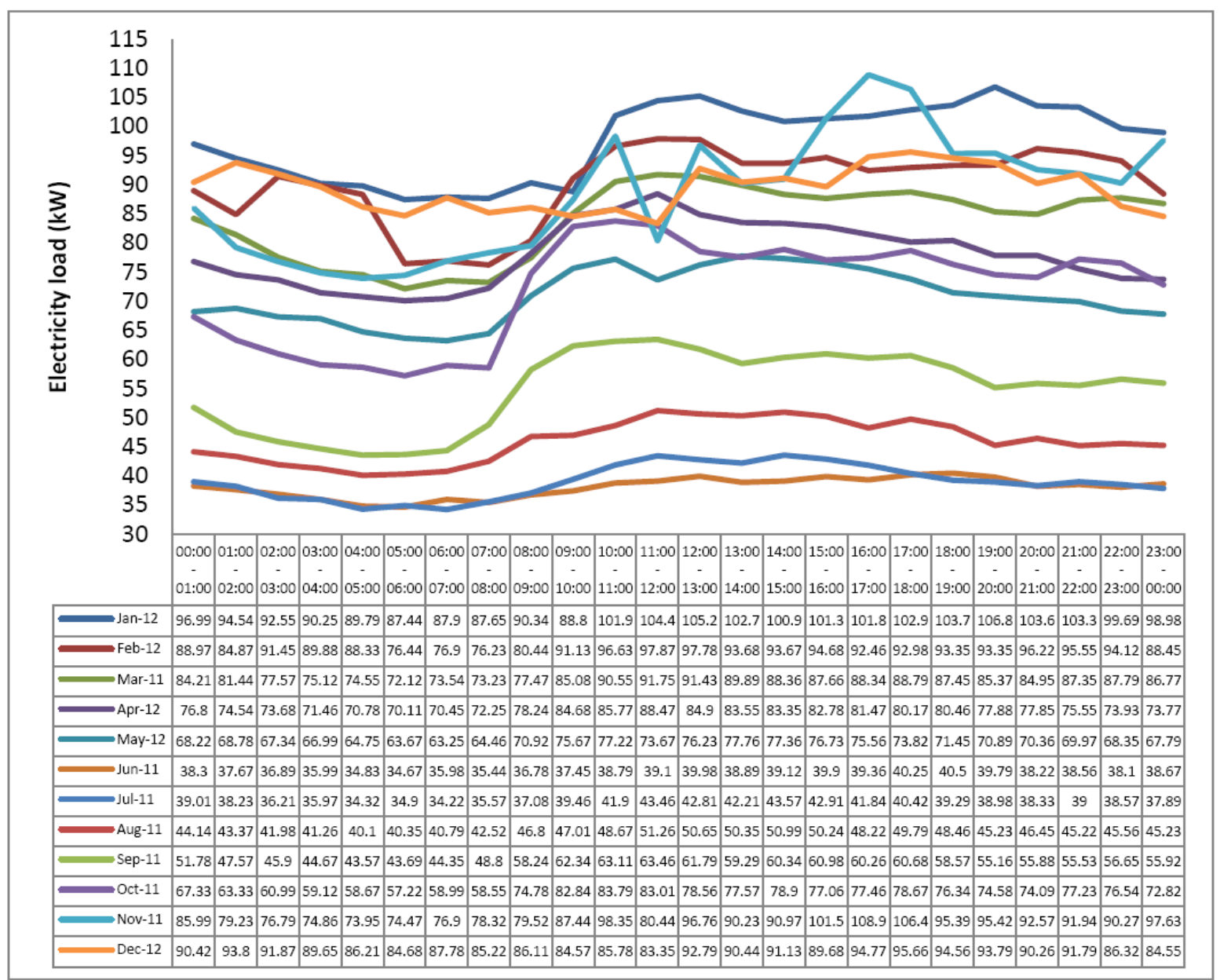

Fig. 2. Grid connected electricity load of Auckland, North Island-New Zealand.

\section{Site SElection AND NumericAl APPROACH}

Solar energy is the major and free RE source available on earth surface. In principal, power with $P V$ modules can be generated regardless of where we are on earth, but the performance of the $P V$ differs region to region. During the time of site selection, a place which has maximum sun exposure frequently and regularly should be opted [1]. However there are various other factors such as de-rating factor, area availability, and distance of the plant from the utilities (load); to establish transmission lines to supply electricity.

A numerical approach was performed among selected major cities in North Island- New Zealand to identify maximum solar elevation available, and the mean annual solar energy available in at each location was collected from NASA. Therefore from the study, I determined that Auckland is the best suitable place for $P V$ based power plant, and the remaining un-met electricity is supplied through biomass generator.

The electricity generated from $P V$ modules can be calculated using (1) [6]

$$
\mathrm{P}_{P V}=Y_{P V} f_{P V}\left(\frac{G_{T}}{G_{T, S T C}}\right)\left[1+a_{p}\left(T_{C}-T_{C, S T C}\right)\right]
$$

where $Y_{P V}$-rated capacity of $P V$ array, meaning power
Output, considering standard conditions in Kilo Watt $(\mathrm{kW})$ $f_{P V}-P V$ de-rating [\%]

$G_{T}$ - solar radiation exposure on $P V$ module $\left[\mathrm{kW} / \mathrm{m}^{2}\right]$

$G_{T, \mathrm{STC}}$-incident radiation, considering standard test conditions $\left(1 \mathrm{~kW} / \mathrm{m}^{2}\right)$

$a_{p}$-temperature coefficient of power $\left[\% /{ }^{0} \mathrm{C}\right]$

$T_{C}-P V$ cell temperature in current time step $\left[{ }^{0} \mathrm{C}\right]$

$T_{C, \text { STC }}-P V$ cell temperature, considering standard conditions $\left[25^{\circ} \mathrm{C}\right]$.

\section{A. Solar Altitude/Elevation}

The solar altitude or solar elevation varies for different geographical location. As New Zealand is located in the northern hemisphere, the solar declination $(\delta)$ can be calculated using (2), and is as shown in the Fig. 3. Solar elevation ( $\alpha$ ) for mid noon can be calculated using (3) and is shown in Fig. 4. [7].

$$
\begin{gathered}
\delta=23.45+\sin \left[(284+n) \times \frac{360}{365}\right] \\
\alpha=90-(\phi-\delta)
\end{gathered}
$$

where, $\phi$ is location latitude, $\delta$ - Solar declination can be calculated using (2) [8], 


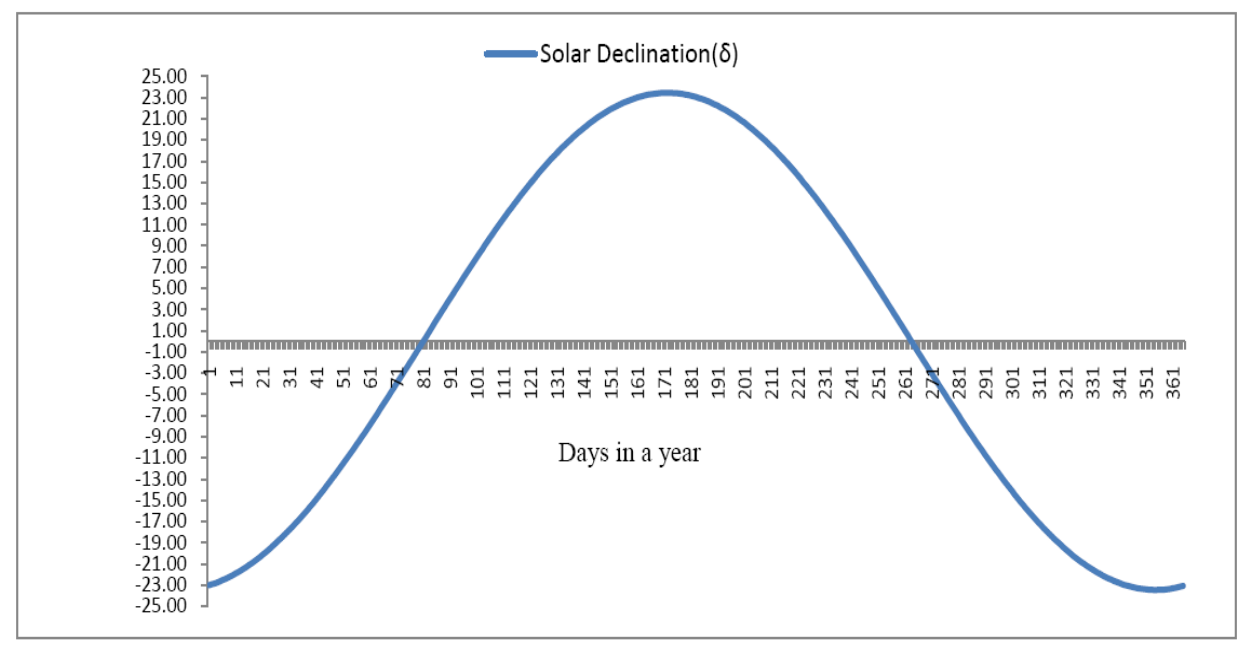

Fig. 3. Solar declination for Northern hemisphere.

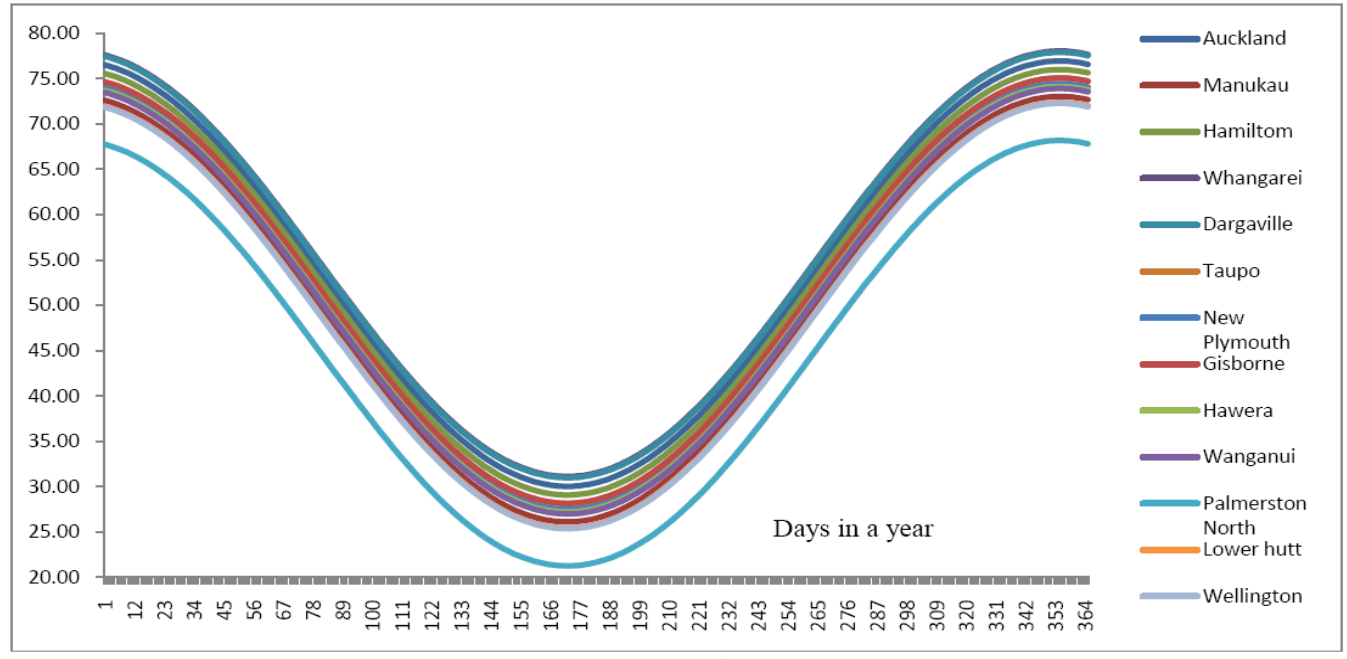

Fig. 4. Solar declination for major cities.

Using the obtained solar declination and location latitude detail, the solar elevation (in degrees) is a shown in Fig. 4. Fig. 4. illustrates Dargaville and Auckland has $1^{\text {st }}$ and $2^{\text {nd }}$ highest solar elevation among all other cities.

The solar data was collected from NASA [9], from the collected data and calculated solar elevation a ranking system was performed and is listed as shown in Table I. Despite Dargaville has the highest solar exposure, Auckland has been opted as the best suitable location, because it eliminates huge investments and losses occurred due to transmission networks. Therefore, the proposed location i.e. Auckland was selected as the best feasible site location.

TABLE I: SOLAR ENERGY RANKING OF MAJOR CITIES IN NORTH ISLAND

\begin{tabular}{lllll}
\hline \hline City & Latitude(South) & Longitude (East) & $\begin{array}{l}\text { Annual solar radiation } \\
\text { (average) } \mathrm{kWh} / \mathrm{m}^{2}\end{array}$ & $\begin{array}{l}\text { Solar } \\
\text { ranking }\end{array}$ \\
\hline Dargaville & 35.57 & 173.52 & 4.28 & 1 \\
Auckland & 36.52 & 174.10 & 4.23 & 2 \\
Lowe Hutt & 41.10 & 174.55 & 4.05 & 3 \\
Wellington & 41.19 & 174.46 & 4.05 & 3 \\
Whangarei & 35.43 & 174.21 & 3.94 & 5 \\
Hamilton & 37.47 & 175.19 & 3.88 & 6 \\
Gisborne & 38.39 & 178.05 & 3.78 & 7 \\
Wanganui & 39.56 & 175.30 & 3.72 & 8 \\
Manukau & 40.43 & 175.13 & 3.72 & 8 \\
Taupo & 38.41 & 176.70 & 3.70 & 10 \\
Hawera & 39.35 & 174.19 & 3.66 & 11 \\
New plymouth & 39.04 & 174.05 & 3.66 & 11 \\
Palmerston North & 45.29 & 170.43 & 3.41 & 13 \\
\hline \hline
\end{tabular}

\section{ECONOMIC ANALYSIS}

The purpose of modeling HPS is to investigate economic analysis. Hybrid Optimization Model for Energy Renewable
(Homer) is a software tool which is used to identify the feasibility study and cost analysis of the system for HPS. The Net present cost (NPC), capital recovery factor (CRF (\$)), and Cost of electricity (COE (\$)) are calculated using (3), (4), and (5). 


$$
\operatorname{NPS}(\$)=\frac{T A C}{C R F}
$$

$i$ - Annual real interest rate (\%).

where, TAC (\$)- Total annualized costs

$$
\operatorname{CRF}(\$)=\frac{i(1+i)^{N}}{(1+i)^{N}-1}
$$

where, $C_{\text {ann,tot }}$ - Annual total cost in (\$).

$E$ - Total electricity consumption, $\mathrm{kWh} /$ year.

Equation (3)-(5) [10]

$$
\operatorname{COE}(\$ / \mathrm{kW} / \mathrm{h})=\frac{C_{\text {ann,tot }}}{E}
$$

where, $N$ - number of years

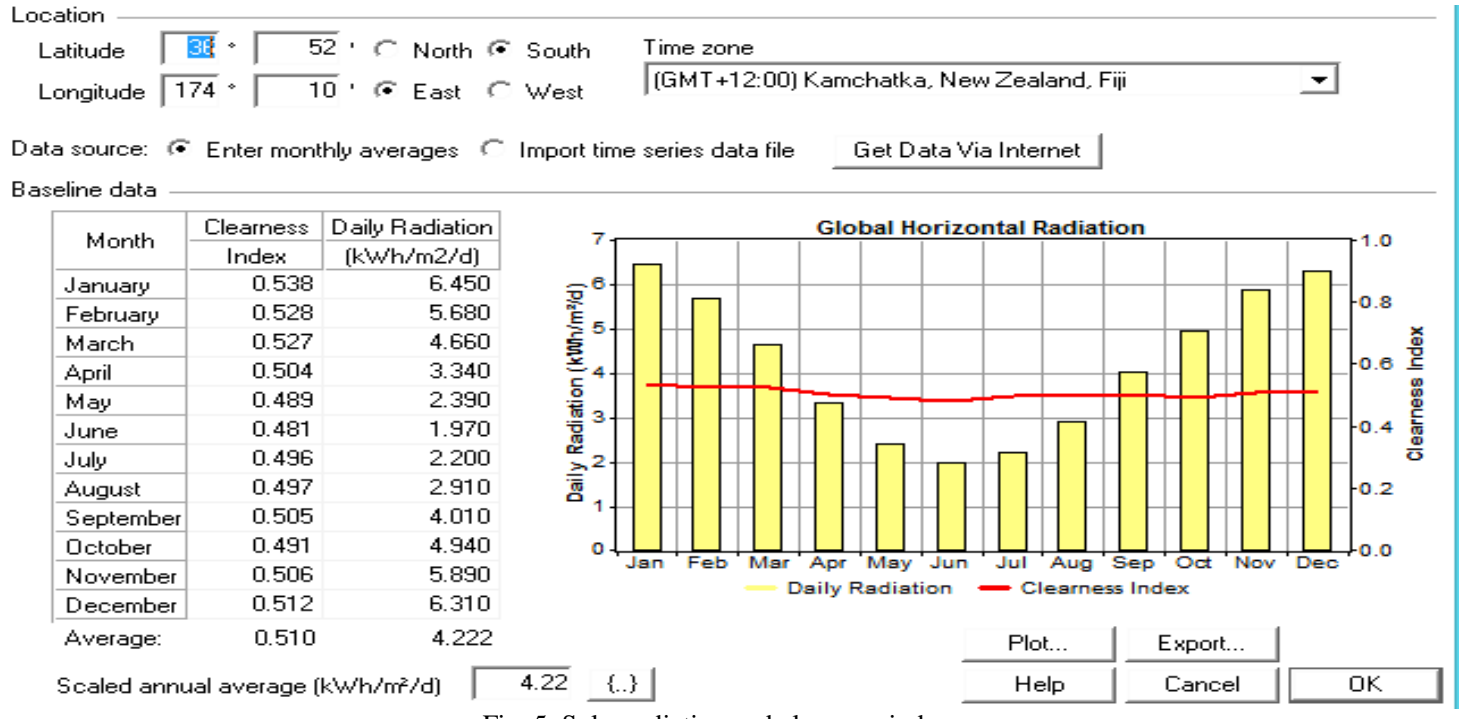

Fig. 5. Solar radiation and clearness index.

connected to the PV output. The converter cost and

\section{SYSTEM COMPONENTS, COST AND INFORMATION}

\section{A. Solar Radiation and Clearness Index}

The solar radiation and clearness index is as shown in the Fig. 5. The proposed site location solar radiation was imported in HOMER computer model and clearness index of 36.52 South Latitude, 174.10 East Longitude as shown in the figure. Annually an average of $4.22 \mathrm{kWh} / \mathrm{m}^{2} / \mathrm{d}$ of solar radiation is available and a clearness index of 0.510 was obtained.

\section{B. PV Module}

The $P V$ output majorly depends on the available solar radiation, the lesser the solar radiation the lesser the $P V$ output. Therefore $P V$ doesn't work when there is no solar radiation. The $P V$ module designed in HOMER produces DC output. A $600 \mathrm{~kW} \mathrm{PV}$ was sized after considering various system losses to supply electricity to the primary load. The input cost and information is listed in Table II.

TABLE II: PV MODULE COST AND INFORMATION

\begin{tabular}{ll}
\hline \hline Description & Cost/Information \\
\hline Capital cost & $\$ 1000.00$ per KW \\
Replacement cost & $\$ 800.00$ per KW \\
Life time & 25 years \\
$P V$ tracking system & No tracking \\
De-rating factor & $85 \%$ \\
Slope & $36.8667^{\circ}$ \\
Azimuth & $180^{\circ}$ \\
Ground reflectance & $20 \%$ \\
\hline \hline
\end{tabular}

\section{Converter}

A converter is used to convert direct current (DC) to alternative (AC), as the output from $P V$ is DC; where as the primary load only consumes AC. Hence a converter was information is listed in Table III.

TABLE III: CONVERTER COST AND INFORMATION

\begin{tabular}{ll}
\hline \hline Description & Cost/information \\
\hline Capital cost & $\$ 200.00$ \\
Replacement cost & $\$ 170.00$ \\
Efficiency & $90 \%$ \\
Life time & 15 \\
\hline \hline
\end{tabular}

\section{Battery}

A storage device adds a significant advantage for energy management in RE [6]. Solar energy is a free and intermittent resource available in atmosphere, however due to environmental factors; it is not always possible to produce continuous and same energy. Hence to maximize the usage of $\mathrm{RE}$ a battery was added to the system to charge when surplus electricity is available and discharges when demand occurs. The input battery cost and input cost detail in HOMER is as shown in Table IV.

TABLE IV: BATTERY COST AND INFORMATION

\begin{tabular}{ll}
\hline \hline Description & Cost/information \\
\hline Capital cost & $\$ 170.00 / 4 \mathrm{~V} \mathrm{1900 \textrm {AH }}$ \\
Replacement cost & $\$ 130.00 / 4 \mathrm{~V} \mathrm{1900 \textrm {AH }}$ \\
Batteries per string & 1 \\
Float life & 12 years \\
\hline \hline
\end{tabular}

\section{E. Biomass Generator}

A global biomass resource is the vegetation on the surface of the earth. Globally this is around $4500 \mathrm{EJ}\left(4500 \times 10^{18} \mathrm{EJ}\right)$ of energy. Approximately one-half to two-thirds of the biomass produced is regenerated each year [1]. Biomass has advantages over fossil fuels because it is renewable, releases less green house gas emission (GHG), widely distributed, and utilizes waste. NZ is targeting to harvest 130,000 ha/year from 3.2 million ha/year energy forest estate of biomass by 
2050 [3] .Therefore, with the future targets in the area of biomass development; a biomass based generator was included to the proposed system. The input cost and information in HOMER is listed in Table IV.

TABLE IV: BIOMASS GENERATOR COST AND INFORMATION

\begin{tabular}{ll}
\hline \hline Channels & Cost/Information \\
\hline Capital cost & $\$ 1000.00$ per KW \\
Replacement cost & $\$ 800.00$ per KW \\
Generator schedule & All the time \\
\hline \hline
\end{tabular}

\section{F. Cash Flow Summary}

The cash flow summary of the proposed system is as shown in the Fig. 6. Initially, a capital investment of $\$ 600,000$ for PV modules, $\$ 60,000$ for biomass generator, \$ 160,000 for batteries, and 120,000 for converter is necessary to establish the proposed system.

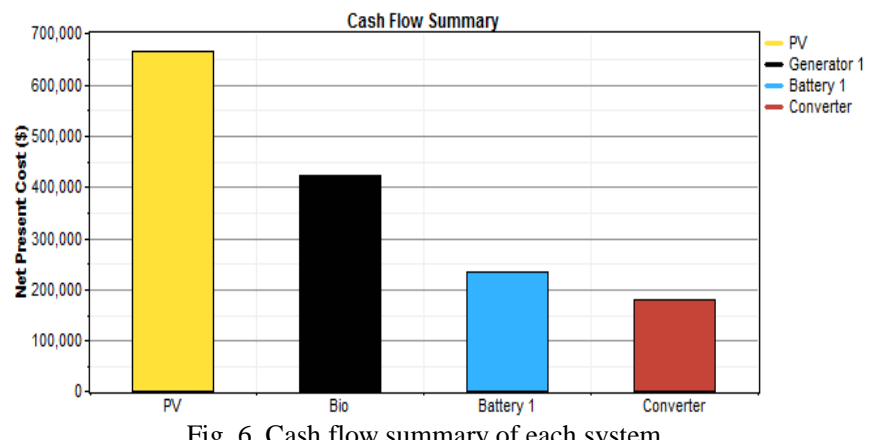

\section{G. Monthly Average Electricity Production}

The average monthly electricity production of the proposed system is as shown in the Fig. 7. Among the output from the modeled system $69 \%$ of the electricity was supplied through $P V$, where as the remaining load was supplied through biomass generator.

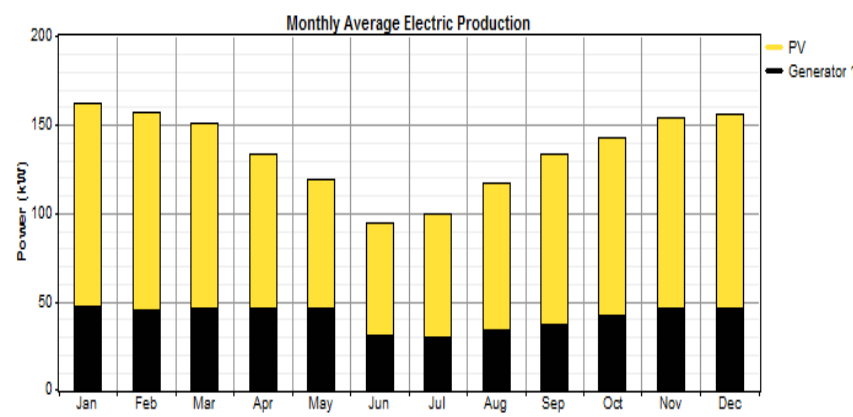

Fig. 7. Average Electricity production monthly.

\section{H. COE of Designed System}

The obtained optimum COE from the designed system is \$ $0.186 \$ / \mathrm{kWh}$, and is as shown in the Fig. 8 .

\begin{tabular}{|c|c|c|c|c|c|c|c|c|c|c|}
\hline \multicolumn{10}{|c|}{ Sensitivity Results Optimization Results } & \\
\hline \multicolumn{11}{|c|}{ Double click on a system below for simudtion results. } \\
\hline 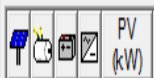 & \begin{tabular}{|l|} 
Bio \\
kWM
\end{tabular} & S4KS25P & $\begin{array}{l}\text { Conv. } \\
\text { (KM) }\end{array}$ & $\begin{array}{l}\text { Initial } \\
\text { Capital }\end{array}$ & $\begin{array}{l}\text { Operding } \\
\text { Cost }(S / y))\end{array}$ & $\begin{array}{l}\text { Total } \\
\text { NPC }\end{array}$ & \begin{tabular}{c|c} 
COE \\
$(S / k W h)$ \\
Fr
\end{tabular} & $\begin{array}{l}\text { Ren. } \\
\text { Frac. }\end{array}$ & $\begin{array}{c}\text { Biomass } \\
\text { (t) }\end{array}$ & $\begin{array}{l}\text { Bio } \\
\text { (hrs) }\end{array}$ \\
\hline 甲10 6000 & 60 & 800 & 600 & $\$ 940,00$ & 40,057 & $\$ 1,452,0$ & $0.186 \quad 1$ & 1.00 & 190 & 8,752 \\
\hline
\end{tabular}

Fig. 8. COE of proposed system.

\section{EMISSION}

Fig. 9. illustrates that with the proposed system model an Emission of $32.8 \mathrm{Kilogram} /$ year $(\mathrm{kg} / \mathrm{yr}), 1.23 \mathrm{~kg} / \mathrm{yr}$ carbon monoxide, $0.137 \mathrm{~kg} / \mathrm{yr}$ unburned hydrocarbons, $0.0929 \mathrm{~kg} / \mathrm{yr}$ particulate matter, 0 sulfur dioxide, and $11 \mathrm{~kg} / \mathrm{yr}$ nitrogen oxides are released. Therefore from the designed system it was revealed that a significant amount of pollutants can be minimized for future sustainability.

\begin{tabular}{|l|r|}
\multicolumn{1}{|c|}{ Pollutant } & Emissions $[\mathrm{kg} / \mathrm{yr}]$ \\
\hline Carbon dioxide & 32.8 \\
\hline Carbon monoxide & 1.23 \\
\hline Unburned hydrocarbons & 0.137 \\
\hline Particulate matter & 0.0929 \\
\hline Sulfur dioxide & 0 \\
\hline Nitrogen oxides & 11 \\
\hline
\end{tabular}

Fig. 9. Emission released from proposed system.

\section{CONCLUSION}

With the recent environmental concerns and for future sustainability has encouraged interests in developing RE based HPS. From the investigation and analytical analysis based on $P V$, and Biomass generator could be a promising solution for future growing electricity consumption, and escalating electricity prices. Therefore with the proposed HPS system 100 percent RE with minimum emission can be achieved. The optimized study of HPS for Auckland showed that the proposed system can be implemented in a cost effective and environmentally friendly manner.

\section{REFERENCES}

[1] P. Breeze, Power Generation Technologies, Burlington, UK: ELSEVIER, 2005

[2] New Zealand Government, "New Zealand energy strategy 2011-2021," Wellington, Government Report, 2011.

[3] SCION, Bioenergy Options for New Zealand.

[4] G. Kelly, "History and Potential of Renewable Energy Development in New Zealand," Research Online, pp. 1-22, 2011.

[5] New Zealand Government, "About the New Zealand electricity sector," Wellington, Government Report.

[6] M. T. O. Amanullah, A. B. M. S. Ali, and M. T. Arif, "Investigation of energy storage systems, its advantage and requirement in various locations in Australia," Journal of Renewable Energy, pp. 1-15, 2013.

[7] mypages. mypages.iit.edu. [Online]. Available: http://mypages.iit.edu/ maslanka/SolarGeo.pdf

[8] G. N. Tiwari and S. Dubey, "Solar radiation," in Photovoltaic Modules and Their Applications: Royal Society of Chemistry, 2010, ch. 1, pp. $1-27$.

[9] Surface meteorology and solar energy. [Online]. Available: https://eosweb.larc.nasa.gov/sse/RETScreen/ March 2008.

[10] P. Gilman, P. L. T. Lambert, "Micropower system modeling with HOMER," in Integration of Alternative Sources of Energy, John Wiley \& Sons, Inc., 2006, ch. 15, pp. 379-417.

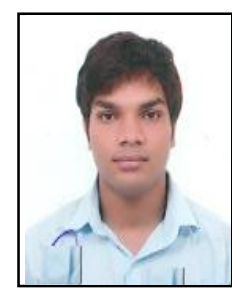

Harish Kumar R. N. is a member of IACSIT. He was born in Andhra Pradesh, India on July 6, 1989 $\mathrm{He}$ received bachelors of engineering $(\mathrm{BE})$ degree in Mechanical Engineering from Nitte Meenakshi Institute of Technology Bangalore, Karnataka stateIndia in the year 2011, and currently pursuing masters of engineering (professional), with a specialization in Renewable Energy at Deakin university, Geelong, Victoria State-Australia. 